\title{
DEGRADASI POLIBLEND POLI(ASAMLAKTAT-KO-ASAMGLIKOLAT) DENGAN POLI(E-KAPROLAKTON) SECARA IN VITRO
}

\author{
Tetty Kemala, Achmad Sjahriza, Hendra Adijuwana, Mardiana Hardianti \\ Departemen Kimia FMIPA IPB Bogor \\ Email : tetty.kemala@gmail.com
}

\begin{abstract}
Polymer has many applications in human life, one of them is in the field of health. Polymer synthetics like polylactic acid (PLA), polyglycolic acid (PGA), poly( $\varepsilon$-caprolactone) (PCL), and poly(lactic acid-co-glycolic acid) (PLGA) were kind of polyesters that is many used in field of health. Many researchers have already made research about degradation of PLA, PGA, PCL, and PLGA. However, there is no one doing research about degradation of combination between this two polymers, one of them is polyblend of PLGA and PCL. Polyblend were made of four compositions, that were PLGA(90:10):PCL 3:1, PLGA(75:25):PCL 3:1, PLGA(90:10):PCL 5:1, and PLGA(75:25):PCL 5:1. Degradation was carried out for eight weeks by using phosphate buffer $\mathrm{pH} 7.4$ and incubation temperature of $37^{\circ} \mathrm{C}$. Degradation of the polymer was observed by mass remained, and intrinsic viscosity. The result showed that composition PLGA(75:25):PCL 5:1 was the fastest in degradation compared to other compositions. It was showed by the decrease in mass until $89.06 \%$ and the change in intrinsic viscosity until $20.13 \%$.
\end{abstract}

Keywords: PLGA, PCL

\section{DAFTAR PUSTAKA}

1. A, Porjazoska, et al., Synthesis and characterization of biocompatible multicomponent polymer systems as supports for cell cultures. Buletin of the chemists \& tecnologiest of Macedonia, 23: 147-156, (2004).

2. R. Sujatmiko, Pencirian poliblend kopolimer poli(asamlaktat)poli(asamglikolat) dengan poli( $\varepsilon^{-}$ kaprolakton), Bogor, Fakultas Matematika dan Ilmu Pengetahuan Alam, Institut Pertanian Bogor, 2007.

3. Kiretmici-Gumusdereliouglu, G. Deniz, Synthesis, characterization and in vitro degradation of poly(d,1-lactide)/poly(d,1lactide-co-glycolide) films, Turk. J. Chem., 23: 153-161, (1999).

4. S. Matsumura, Mechanism of biodegradation, Biodegradable Polymers for Industrial Applications, Smith R, England, Woodhead Publishing, , 2005,357-361, 365-369..
5. P. A. Gunatillake, A. Raju,. Biodegradable synthetic polymers for tissue enginerring, Eur Cells and Materials, 5: 1-16, (2003)

6. S. J. Huang, P. G. Edelman, An overview of biodegradable of polymer, Degradable Polymers: Principles \& Applications, $\mathrm{Scott}$ G, Dan G, London: Chapman \& Hall, 1995,18-19.

7. Bhattacharya, R. L. Reis, V. Correlo, L. Boesel, Material properties of biodegradable polymers, Biodegradable Polymers for Industrial Applications, R. Smith, Woodhead Publishing, England, 2005, 343-345.

8. Porjazoska A et al.,. Poly(lactide-coglycolide) microparticles as system for controlled release of protein-preparation and characterization, Acta Pharm., 54: 215-229, (2004a)

9. U. Edlund, A. C. Albertson, Degradable Polymer Microsphere for Controlled Drug Delivery, Degradable Aliphatic Polyesters, Albertson A. C, New York, Springer, 2002, 70-85. 
10. D. M. Billings, Lippincott's Review for NCLEX-RN, Philladelphia, Lippincott Williams \& Wilkins, 2005.

11. Saladin, Human Anatomy, New York, McGraw, 2005
12. T. D. Farahani, A. A. Entezami, H. Mobedi, M. Abtahi, Degradation of poly(d,1-lactide-co-glycolide) $\quad 50: 50$ implant in aqueous Medium. Iranian Polym. J., 14: 753-763. (2005). 